\title{
História e conhecimento no Emílio ou da educação, de Jean-Jacques Rousseau*
}

\author{
Rogério Silva de Magalhães \\ Universidade Federal de São Paulo
}

$\mathrm{E}$

ste breve estudo visa estabelecer uma relação entre história e conhecimento no Livro IV do Emílio (1762). Nesse sentido, procuraremos mostrar que JEAN-JACQUES ROUSSEAU (1712-78) considera o estudo da história no alvorecer da idade adulta da forma como era concebida em seu tempo como algo pernicioso para a formação do homem. Antes de prosseguirmos, é interessante notar que a concepção rousseauniana contrasta com a dos pensadores franceses do Iluminismo ${ }^{2}$, além de diferir também daquela proposta por IMMANUEL KANT (1724-1804), outro grande filósofo da época. No filósofo de Königsberg, encontramos um conceito de história orientado pelo progresso. $\mathrm{E}$ a razão está a serviço de um progresso ético e político. Em sua Idéia de uma história universal de um ponto de vista cosmopolita (1784), o filósofo alemão afirma o seguinte:

De um ponto de vista metafísico, qualquer que seja o conceito que se faça da liberdade da vontade, as suas manifestações (Erscheinungen) - as ações humanas -, como todo outro acontecimento natural, são determinadas por leis naturais universais. A história, que se ocupa da narrativa dessas manifestações, por mais profundamente ocultas que possam estar as suas causas, permite todavia esperar que com a observação, em suas linhas gerais, do jogo da liberdade da vontade humana,

\footnotetext{
"History and knowledge on Book IV of Emile, or on Education by J.-J. Rousseau.

Endereço para correspondências: Rua Alberto Lohnhoff. 642, Lauzane Paulista, São Paulo, SP, 02443-010 (rmagalhaes@unifesp.br).

${ }^{2}$ Para Salinas Fortes, o Iluminismo proclamava o Império da Razão. Ela deve ser soberana e autônoma. Isso significa que a razão atingiu um estágio diferenciado em relação ao passado. Surge assim a idéia de progresso do homem. "Os homens percebem através do estudo do seu passado, que a massa de conhecimentos adquiridos pode ser utilizada e posta a serviço do seu proprio bem-estar. Surge, por conseguinte, como um corolário necessário de todas estas descobertas, um novo mito, um novo ideal, uma nova idéia reguladora, ou seja, a idéia do Progresso" (FORTES, 1981; p. 20). Em seu Ilustração e história: o pensamento sobre a história no Iluminismo francês, Maria das Graças de Souza afirma que a crítica contundente de Rousseau ao progresso histórico do homem na Época das Luzes reside na sociedade de ostentação de sua época, a qual ele via como degenerada. "A crítica do progresso remete-nos à posição de Rousseau na polêmica sobre o luxo no século XVIII" (SOUZA. $2001 ;$ p. 79). A sociedade do luxo prioriza a aparência e está pautada na desigualdade. Ora, os homens dessa sociedade estão mais distantes da virtude. Uma história baseada no luxo não é. portanto, útil para a educação do Emílio.
} 
mais próximo de um homem natural. Esse modelo de história privilegia somente certos momentos da vida dos personagens nos quais eles se encontram adornados e raramente retratados em suas atividades cotidianas.

\begin{abstract}
[...] A história mostra muito mais as ações do que os homens, porque ela só os toma em certos momentos escolhidos, com seus trajes de gala; ela só mostra o homem público que se arrumou para ser visto; não o segue em sua casa, em seu escritório, na família, junto aos amigos; só o retrata quando ele representa; ela pinta muito mais a sua roupa do que a sua pessoa (Ibid., p. 332).
\end{abstract}

É por essa razão que Rousseau critica veementemente a história moderna porque ela mostra um homem encoberto por máscaras. Esse homem está sempre preocupado com a sua aparência perante os outros e, por consequiência, com o conceito que o outro formula sobre ele. Ou seja, o homem não se dá a conhecer. "A história moderna, segundo Rousseau, preocupa-se em fazer belos quadros. Assim, é o historiador que brilha, e a verdade fica em segundo plano" (SOUZA, 2001; p. 60).

Esse argumento de Jean-Jacques leva o próprio autor a reinvidicar a leitura do que se tornaria conhecido no século $\mathrm{XX}$ por história da vida privada. Esse modelo de história oferece ao leitor uma possibilidade de conhecer o homem despido, de maneira geral, de suas máscaras.

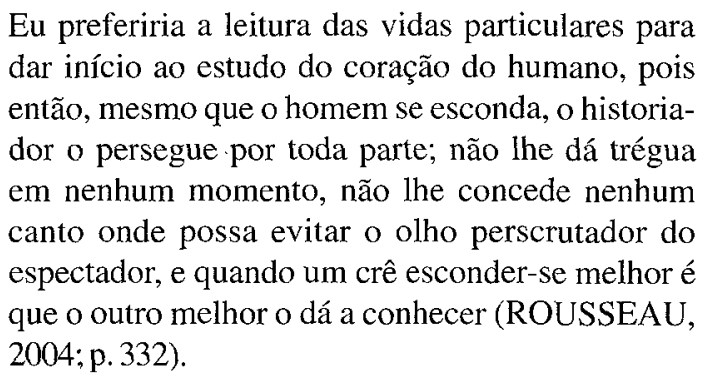

O percurso realizado até o momento permitiu-nos delinear o desenvolvimento de uma concepção crítica da história no pensamento rousseaniano contido no capítulo IV do Emílio. Não obstante, talvez seja possível até mesmo dizer que Rousseau desenvolve uma espécie de modelo de teoria da história voltada para a educação. Se, por um lado, para ele, o passado dos grandes nomes da história, por exemplo, não pode ser necessariamente ignorado, por outro, esse conhecimento não terá utilidade alguma, sobretudo pedagógica, 
se a narrativa lida for a das guerras, a das máximas, a dos desejos de glória, a da empolação envolvendo esses nomes, a qual só deve ser lida na maturidade. "Tácito é o livro dos velhos, os jovens não são feitos para entendê-lo [...]" (ROUSSEAU, 2004; p. 331). Não se pode negar assim a predileção de JeanJacques pela historiografia antiga para a educação do Emílio. Porém, é digno de nota que ele também estabelece algumas restrições aos historiadores antigos. Ele não recomenda Políbio, nem Salústio e nem Tácito. Por outro lado, ele elogia Plutarco. "Tem uma graça inimitável para retratar os grandes homens nas pequenas coisas [...]" (Ibid., p. 333). A esse respeito, Maria das Graças de Souza afirma o seguinte:

As Vidas de Plutarco contribuirão para que Emílio não se deixe enganar pelo jogo das paixões. Não é que Emílio, ao final das leituras, queria ele mesmo tornar-se um herói da Antiguidade, mesmo que fosse Sócrates ou Catão. [...]. A história será, para Emílio, um instrumento de conhecimento da alma humana e de si mesmo (SOUZA, 2001; P. 66).

Assim, considerando isoladamente este capítulo do Emílio, podemos concluir que o filósofo genebrino tece uma crítica à historiografia de sua época, por conseguinte, uma crítica da modernidade pautada em um suposto "progresso". Além disso, no Emilio, a história deve ajudar o indivíduo a viver melhor em uma sociedade corrompida. O estudo da história deve ajudar a conhecer o homem e servir como termômetro para a própria vida, mas, sobretudo, deve permitir ao Emílio conhecer a depravação da sociedade sem que seja necessário experimentar no cotidiano essa corrupção.

[...] A história preconizada por Rousseau é, antes de tudo, uma história exemplar. Exemplar, no sentido de ser uma história da qual se podem extrair lições morais. Antes de o jovem ser capaz de ler a história nesta perspectiva, é absolutamente inútil e mesmo prejudicial ensinar-lhe história (SOUZA, 2001; p. 49).

\section{Referências bibliográficas}

FORTES, L.R.S. O iluminismo e os reis filósofos. São Paulo: Brasiliense, 1981 (Col. Tudo é história). 
KANT, I. Idéia de uma história universal de um ponto de vista cosmopolita. Trad. R. Naves e R.R. Terra. São Paulo: Martins Fontes, 2003.

KANT, I. Resposta à pergunta: que é o Iluminismo? In: A paz perpétua e outros opísculos. Trad. Artur Mourão. Lisboa: Edições 70, 2004 (Col. Textos Filosóficos).

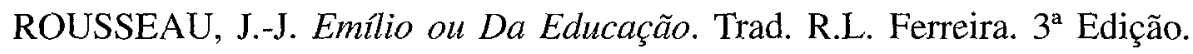
São Paulo: Martins Fontes, 2004.

SOUZA, M. das G. de. Ilustração e história: o pensamento sobre a história no Iluminismo francês. São Paulo: Discurso editorial, 2001. 